\title{
EXPLORING EFL TEACHERS' STRATEGIES IN TEACHING READING COMPREHENSION: A CASE OF THE SCHOOLS AT LIMITED RESOURCES AREAS
}

\author{
${ }^{1}$ Megawati Basri; ${ }^{2}$ Balqis Husain; ${ }^{3}$ Yana Nadila Nyimo \\ 1,2,3 Universitas Pasifik Morotai, \\ Correspondence E-mail: balqishusain.bh@gmail.com
}

\begin{abstract}
This study aims to examine teachers' strategies in understanding reading. This study was carried out in the EFL class in the limited resources areas; the researcher investigated the teacher strategy for variations to help the students to grasp reading comprehension materials. Qualitative analysis was formulated for this research. Forty-nine respondents from 11 schools represented at the Secondary School and High School in Pulau Morotai. The researcher tested the teachers who had been formed in questionnaire tests in this test. The questioner consisted of 25 items, in which the teachers had to select one of the possible alternatives. This is test' advantage was to know the dominant techniques the English teacher used in classroom of reading comprehension. Response criteria were shared with respondents using a Likert scale questionnaire. There are five answers, which range from strongly agree to disagree strongly. In this data collection procedure, all of the items were inserted in the google-form. Then the researcher shared the link of the questionnaire for all English teachers of Junior High School and Senior High School at Morotai Timur and Morotai Selatan. The link was shared through social media such as Whatsapp platform, and respondents' answer were calculated by SPSS 17 for windows. The researcher found that only 49 respondents volunteered to complete this form. Teachers' methods in understanding teaching lectures were presented at three phases: pre-reading phases, reading phases, and post-reading phases. The Post-reading phase was favored for much less than the pre-reading and while-reading phase. The data showed that the while-reading stage was the lowest among the other stages; this was evidenced by its mean value of 4.51 . The second stage was the pre-reading stage, with a mean score of 28.55, and the highest mean score on the post-reading stage was 28.67.
\end{abstract}

Keywords: EFL, strategies, teaching, reading comprehension, limited resources areas

\section{INTRODUCTION}

It is commonly believed that the majority of the students in Indonesia have a little bit of interest in reading. Indonesian tends to oral culture rather than a literacy culture. On the other hand, most of the society in Indonesia is not a society book reader yet. The report of World Bank No 16369-IND and a study has been conducted by IEA (International Association for the Evaluation of Education Achievement) of North Asia showed that the Indonesian holds the lowest level of children's reading. Another study has been done by PIRLS (Progress in International Reading Literacy Study). This global survey focuses on the area of children's reading around the world. This study reveals 
that the averages of Indonesia's child ranks are fourth from the bottom compared with 45 countries worldwide. Indonesia's score is (51.7), below one level of Philippines, with the score (52.3), then it is followed by Thailand (65.1), Singapore with percentage (74.0), and Hongkong with a total score (75.5).

Handayani \& Setiawan (2018) argue numerous reasons lead students to be the lowest in reading skill. First, the Family environment does not support the reading habit. Second, the low purchasing of reading books due to most of the society comes from low-income families. Third, the minimum number of libraries inadequate conditions. Fourth, the negative impact of rapid Technology and Information. The last is the learning model, which the teachers prepare do not require the students to be the reader.

A case study in Saudi schools has been voiced by Al-Qahtani (2016) many other Saudi EFL learners total absence the read habits needed for L1 and L2. When reading English texts, they hardly ever use essential reading skills. In this report, a lack of target language was identified. Such as lack of teaching ability and qualified teachers, the little emphasis given to understanding and attention paid to reading aloud, loss of enthusiasm for students, even less concentrate on literacy comprehension in reading materials, inexperienced and unfit literacy subject matters, and also lack of learner reading skill development, as well as the limited vocabulary of students. Regrettably, lack of parental responsibility has become the most responsible factor behind Saudi students' poor readability.

Reading ability is regarded as the most prominent of four academic purposes, mainly English as a second or foreign language learner (Soemantri, 2011). While reading comprehension plays a fundamental role in language acquisition and learning, the EFL learners should master that. The top reading skills and the basis for all reading activities are reading comprehension (Astuti, 2018). Therefore, the teachers who teach reading comprehension in EFL classrooms should have good reading comprehension, knowing exactly to find appropriate instructional methods, materials, activities, media, strategy, and equipment, in order to assist the students' improvement in their reading comprehension skills and good sensitivity to understand the students' needs. Razali \& Razali (2013), suggest two prominent vital strategies that can be adopted in language learning. Both of them are direct and indirect language learning strategies. These can also be classified into three classes: recall, analytical and compensatory, and meta- 
cognitive, affective, and social approaches. Every single of them has conveniences and limitations. Teachers guide students in the classroom to be proficient and active readers in productive learning of reading understanding. Creative teachers should not use only one single approach but incorporate a broad range of techniques and skills to suit each student's needs and styles in the class (Muslaini, 2017). On the other hand, teaching reading comprehension can be taught with various strategies, and it must be transformed based on students' needs. Indeed, Creating teachers produce better outcomes regardless of the actual curricula, pedagogical knowledge. The above points indicate that the teacher plays an integral part in educating students. The use of curriculum in public schools requires some aspects of the learning program. Aspects of the learning program include how students present, how they respond, their involvement in learning, and the addition of strategies, methods, and learning techniques (Husain et al., 2019).

Based on the researchers' observation, most middle school and high school students are still lacking in reading their understanding, finding, in particular, the central ideas of the text, finding explicit and implicit content, identifying references to the words, and identifying the meaning of certain words. This phenomenon should be further analyzed to determine what exactly affects students' ability to understand the reading. Nurhaidah and Musa (2016:2) claim that increasing the students' interest and students' reading ability is very apprehensive. The strategies that the teachers implement do not attract the students' attention and do not pleasure. Most of the strategies tend to the result-oriented rather than process-oriented. Pourhosein Gilakjani $\&$ Sabouri (2016) the critical point in reading comprehension is that active readers could accurately predict which tactics to adopt and when to use them. Numerous students may receive specific guidance in applying suitable techniques to understand a text.

As the upgrading the existing, the present study aims to examine teachers' strategies in understanding reading. This study was carried out in the EFL class in the limited resources areas; the researcher investigated the teacher strategy for variations to help the students to grasp reading comprehension materials.

\section{METHOD}

Qualitative analysis was formulated for this research. Forty-nine respondents from 11 schools represented at the Secondary School and High School in Pulau Morotai. This research was carried out in June 2020. The researcher tested the teachers 
who had been formed in questionnaire tests in this test. The questioner consisted of 25 items, in which the teachers had to select one of the possible alternatives. This test's advantage was to know which was the dominant technique the English teacher used in the classroom of reading comprehension. Response criteria were shared with respondents using a Likert scale questionnaire. There are five answers, which range from strongly agree to disagree strongly.

In this data collection procedure, the researcher provided several items of statements, all of the items were inserted in the google-form. Then the researcher shared the link of the questionnaire for all English teachers of Junior High School and Senior High School at Morotai Timur and Morotai Selatan. The link was shared through social media such as Whatsapp platform, and respondents' answer were calculated by SPSS 17 for windows. The researcher found that only 49 respondents volunteered to complete this form. Then the researcher tried to utilize in order to know the distribution of the respondents' answers.

\section{FINDING AND DISCUSSION}

In this research, the researcher has measured the strategy used by the teacher in teaching reading. To assess what strategy the teacher used, the researcher used a questionnaire. Before applying this questionnaire, it should have been measured their validity. In this research, the researcher used SPSS 17. The table below shows that there were 49 respondents in which all respondents are valid.

Table 1. Respondents' Demographics and Cumulative Percent

\begin{tabular}{|l|c|c|c|}
\hline Classification & Frequency & $\begin{array}{l}\text { Valid } \\
\text { Percent }\end{array}$ & $\begin{array}{l}\text { Cumulative } \\
\text { Percent }\end{array}$ \\
\hline $\begin{array}{l}\text { Teachers of } \\
\text { Junior High } \\
\text { School }\end{array}$ & 24 & 49.0 & 49.0 \\
\hline $\begin{array}{l}\text { Teachers of } \\
\text { Senior High } \\
\text { School }\end{array}$ & 25 & 51.0 & 100.0 \\
\hline Sex & & & \\
\hline Female & 15 & 30.6 & 30.6 \\
\hline Male & 34 & 69.4 & 100.0 \\
\hline
\end{tabular}


Table 1 reveals that 49\% (24) teacher of the Junior High School participated as the respondent in filling the questionnaire. Whereas in Senior High School, there were 25 teachers $(51 \%)$ who participated in this research. The respondents consisted of 34 males and 15 females.

There were three phases of Reading: The pre-Reading Stage, While-Reading Stage, and Post-Reading Stage in the Reading teaching strategy. Each of them was discussed in this section.

Table 2.Validity Test of Pre-Reading Stage

\begin{tabular}{|c|c|c|c|r|}
\hline $\begin{array}{l}\text { No of } \\
\text { Items }\end{array}$ & $\begin{array}{c}\text { Corrected Item } \\
\text { Total Correlation }\end{array}$ & $\begin{array}{c}\text { r-table } \\
(5 \%)\end{array}$ & Sig & Criteria \\
\hline 1 & $.318^{*}$ & 0.281 & .026 & Valid \\
\hline 2 & $.541^{* *}$ & 0.281 & .000 & Valid \\
\hline 3 & .243 & 0.281 & .092 & Invalid \\
\hline 4 & $.282^{*}$ & 0.281 & .049 & Valid \\
\hline 5 & $.693^{* *}$ & 0.281 & .000 & Valid \\
\hline 6 & $.626^{* *}$ & 0.281 & .000 & Valid \\
\hline 7 & $.674^{* *}$ & 0.281 & .000 & Valid \\
\hline
\end{tabular}

At the Pre-Reading Stage table above, six items were valid, and only one item was invalid. So, item number 3 cannot be used as a questionnaire to collect the data.

Table 3. Validity Test of While-Reading Stage

\begin{tabular}{|c|c|c|c|r|}
\hline $\begin{array}{c}\text { No of } \\
\text { Items }\end{array}$ & $\begin{array}{c}\text { Corrected Item } \\
\text { Total Correlation }\end{array}$ & $\begin{array}{c}\text { r-table } \\
(5 \%)\end{array}$ & Sig & Criteria \\
\hline 8 & $.651^{* *}$ & 0.281 & .000 & Valid \\
\hline 9 & $.629^{* *}$ & 0.281 & .000 & Valid \\
\hline 10 & $.579^{* *}$ & 0.281 & .000 & Valid \\
\hline 11 & $.414^{* *}$ & 0.281 & .003 & Valid \\
\hline 12 & .208 & 0.281 & .151 & Invalid \\
\hline 13 & $.438^{* *}$ & 0.281 & .002 & Valid \\
\hline 14 & .061 & 0.281 & .675 & Invalid \\
\hline 15 & .012 & 0.281 & .934 & Invalid \\
\hline 16 & .087 & 0.281 & .551 & Invalid \\
\hline 17 & .222 & 0.281 & .126 & Valid \\
\hline 18 & .064 & 0.281 & .660 & Valid \\
\hline
\end{tabular}


The table of the While- Reading Stage above shows that four items are invalid and seven valid items. It means the item number $12,14,15$, and 16 cannot be used as a questionnaire.

Table 4. Validity Test of Post-Reading Stage

\begin{tabular}{|c|c|c|c|r|}
\hline No of items & $\begin{array}{c}\text { Corrected Item } \\
\text { Total Correlation }\end{array}$ & $\begin{array}{c}\text { r-table } \\
(5 \%)\end{array}$ & Sig & Criteria \\
\hline 19 & $.594^{* *}$ & 0.281 & .000 & Valid \\
\hline 20 & $.662^{* *}$ & 0.281 & .000 & Valid \\
\hline 21 & $.572^{* *}$ & 0.281 & .000 & Valid \\
\hline 22 & $.629^{* *}$ & 0.281 & .000 & Valid \\
\hline 23 & $.464^{* *}$ & 0.281 & .001 & Valid \\
\hline 24 & $.566^{* *}$ & 0.281 & .000 & Valid \\
\hline 25 & .126 & 0.281 & .389 & Invalid \\
\hline
\end{tabular}

The Post-Reading Stage table indicates that only one item was declared invalid, and this item was eliminated from the questionnaire.

\begin{tabular}{|c|c|}
\hline \multicolumn{2}{|c|}{ Table 5. Reliability Statistics } \\
\hline Cronbach's Alpha & Numbers of Items \\
\hline 719 & 19 \\
\hline
\end{tabular}

The results of Reliability $(0,719 \%)$ were in high correlation. So, the questionnaire was reliable and could be used for the research.

Table 6. Indicators of Reading Comprehension Strategy

\begin{tabular}{|l|c|c|c|c|c|c|c|}
\hline & $\mathrm{N}$ & $\begin{array}{l}\text { No of } \\
\text { Items }\end{array}$ & Mean & $\begin{array}{l}\text { Std } \\
\text { Deviation }\end{array}$ & Range & Minimum & Maximum \\
\hline $\begin{array}{l}\text { Pre-Reading } \\
\text { Stage }\end{array}$ & 49 & 6 & 28.55 & 3.330 & 13 & 22 & 35 \\
\hline $\begin{array}{l}\text { While-Reading } \\
\text { Stage }\end{array}$ & 49 & 7 & 4.51 & .505 & 1 & 4 & 5 \\
\hline $\begin{array}{l}\text { Post-Reading } \\
\text { Stage }\end{array}$ & 49 & 5 & 28.67 & 3.608 & 12 & 23 & 35 \\
\hline
\end{tabular}

A total of 19 items were contributed to this research. The data shows that respondents were asked to answer six items on the first stage, the Pre-Reading stage. These six questions were related to; Read the title of the given text, determine the reading objective, look for possible answers by reading individual sections only, read the first and last paragraphs, and utilize the background of knowledge to understand the text being read. However, the mean score on this stage was 28.55. In the second stage, 
While-Reading Stage, there were seven questions that the respondents should answer. This Stage was related to Students not directly reading the text from the beginning to the end of the word-by-word, avoiding reading the text repeatedly, making predictions or predicting, and avoiding using bilingual and monolingual dictionaries, and discovering the pattern of developing text against specific markers. The second stage was the lowest stage, with a mean score of 4.51 .

At the last stage, Post-Reading Stage, there were five questions to be solved by respondents. At this stage, respondents were asked to answer questions relating to; Read the question before reading the full-text content and look for the answer, reformulating the text read in its own words, concluding the text content, and evaluating the text by questioning the text content's correctness and answering understanding questions. The last stage was the highest mean score among the other stages; this was evidenced by its mean value of 28.67 .

Nurman (2010) the three reading phases which is used by the teachers increase their efficiency in order to clarify the frameworks, applications and factors behind the use of the teaching comprehension strategies. He also suggests that students with low-level association responses should practice techniques before they start reading and provide some assistance for students with partially established awareness. A previous similar study has been voiced out by Nurman (2010), this study shows that teachers used reading understanding techniques in three phases of reading: before, during, and after reading. In the pre-reading point, brainstorming was used. Students were encouraged even to use a dictionary, communicate text kinds and predict. Then, during their reading, they read aloud, read again to verify understanding, read explicitly, address the unknown words, and retell the text, they developed an assessment of understanding, explanation and rationale, interpretation, review, assignment, and follow-up in the post-reading process. In general, the students' comments to the strategies of their teachers were sufficiently strong, categorized in weak association response rates and partially informed knowledge structure responses. Conversely, a study had been revealed by Al-husban (2019), his study showed that teachers traditionally taught students to reading comprehension. Most of the teachers reported and answered knew the reading strategies' names and the phase of understanding 
reading. Teachers did not even know, after all, what to do to implement and start practicing them.

However, based on Zare's Study (2013), she defines that Iranian EFL learners can be identified as moderate strategy users. The study also indicates that there is no significant gap between men and women language learners in reading strategies. The use of reading strategies was also found to have a significant positive correlation to reading understanding. Previous study has been conducted on Iranian students. It indicates that there has been a substantial positive relationship between the use of critical thinking and reading strategy by readers of Iranian English as a foreign language (EFL) in particular and metacognitive and cognitive reading strategies.

Besides, a strong positive association among both critical thinking and reading compensation was found. Thus it showed that affective and cognitive techniques and critical thinking skills are the strongest predictors of understanding the reading (Hosseini et al., 2012). Alsamadani (2012) claims that Saudi educators firmly believe in the great significance of cognitive strategy instruction and inadequate awareness of metacognitive reading strategies' value. The study concludes with suggestions for training Saudi EFL teachers to prepare, track, assess, and control their learning in the most productive metacognitive reading strategies. Besides, Xu (2015) points out that by enriching the effective pedagogical teaching on instructional strategies. ESL/EFL educators could effectively teach both metacognitions to read strategies. For instance, intentionally organizing, monitoring, and assessing classroom instruction and metacognitive strategies, namely, to affect their students' metacognitive awareness about using the strategic plan in reading..

Similar prior research has been done by Khonamri (2015), he reveals that most teachers claim that reading strategies play a vital role in reading comprehension and that reading strategies must be learned in reading classes. The findings have also been shown that the teachers' views and self-reported classroom practice are contradictory. Nevertheless, the values of students in English learning are influenced by their self-efficacy. Teachers and instructional designers are recommended to improve learners' productivity and help students maintain the right expectations about foreign languages' learning to encourage them (Genç et al., 2016). 


\section{Published by Faculty of Teacher Training and Education University of Abdurachman Saleh Situbondo}

Bamanger \& Gashan (2014), in their present study, revealed that what teachers believe on the appropriate instructional reading methods is very much in line with what they do in classrooms. The results indicate that EFL teachers ought to adjust what they think about these procedures to transform the classroom procedures. Bloemert et al. (2016) add that teachers' preferences do not necessarily contribute significantly to the path to FL literature due to curriculum design legacy or the creation of FL curricula for literature. Interestingly, Anwar et al. (2020) claim several problems face most students during teaching reading in the EFL classroom at rural schools. Such as; learning facilities in electrical power conditions, the low interest and capacity of students in English, and problems of teachers applying are found the latest curriculum where the most exciting concern seemed to be itself.

It is seen, they faced the challenges and the directions they treated them. Their acts revealed their pedagogical existence. There are insufficient knowledge and experience. For instance, the teachers used conventional methods in this study approaches to teach reading comprehension (e.g., a teacher-centered approach and sitting the students in rows). Azizi et al. (2020) argue that refurbishments were the most regularly used form of input in both instructor classes. In addition, both experienced and inexperienced novice teachers tended to use multiple corrective input variations at various distributions. There may be a significant difference between novices' use and experienced teachers' forms of corrective feedback. Concerning the error forms, the data analysis showed that out of four error types, the most common errors committed by EFL students were phonological errors Classes of awareness of reading. Nevertheless, Rahimi \& Weisi (2018) to this end, the EFL teachers in the ELT can enhance their knowledge, realize their classroom issues objectively and logically, work collaboratively with colleagues to discover alternative teaching and hearing problems to instruct and develop students more clearly and appropriately qualification, as well as become a leading figure in the ELT society in this respect. Therefore, EFL Teaching staff is recommended to start engaging in their studies in the educational environment.

\section{CONCLUSION AND SUGGESTION}

Teachers' methods in understanding teaching lectures were presented at three phases: pre-reading phases, reading phases, and post-reading phases. EFL teachers 
showed strong views about the use of reading mechanisms based on the results of the study. Most EFL teachers agree that reading strategies are essential before and after lecture levels. They also promote the use of all activities and enable students to take part in reading activities. On the other hand, the Post-reading phase was favored for much less than the pre-reading and while-reading phase. The data showed that the whilereading stage was the lowest among the other stages; this was evidenced by its mean value of 4.51. The second stage was the pre-reading stage, with a mean score of 28.55 , and the highest mean score on the post-reading stage was 28.67 .

EFL teachers can use this research in restricted areas of resources for EFL teachers to understand the best classroom management methods in the teaching-learning process. Understanding classroom management helps students increase their interest in studying the reading comprehension materials by knowing the technique. It is also easier for teachers to resist the traditional approach when resources such as teacher learning center's techniques are being distributed. In teaching reading comprehension, the insight of EFL teachers toward the competence of instructional practice should be established, particularly in mastering materials and in the use of English in schools. Considering that most EFL teachers in resource-saving areas do not necessarily use English when delivering the materials or giving instruction in the classroom. Besides, this research just involved several schools of the limited resources area in Pulau Morotai. Hopefully, the next research can cover all of Pulau Morotai and the entire limited resources area in North Maluku.

\section{REFERENCES}

Al-husban, N. (2019). EFL Teachers' Practices while Teaching Reading Comprehension in Jordan: Teacher Development Implications. Journal on English as a Foreign Language, 9(2), 127-145. https://doi.org/10.23971/jefl.v9i2.1288

AL-Qahtani, A. A. (2016). Why Do Saudi EFL Readers Exhibit Poor Reading Abilities? English Language and Literature Studies, 6(1), 1. https://doi.org/10.5539/ells.v6n1p1

Alsamadani, H. A. (2012). Reading Strategy Instruction in Saudi Schools. Journal of Language Teaching and Research, 3(5), 829-837. https://doi.org/10.4304/jltr.3.5.829-837

Anwar, K., Faruq Ubaidillah, M., \& Sulistiyo, U. (2020). Exploring EFL Teachers' Classroom Management: The Case of Indonesian Remote Secondary Schools. 


\section{Published by Faculty of Teacher Training and Education \\ University of Abdurachman Saleh Situbondo}

Journal of Language and Education, 6(3), 22-35.

https://doi.org/10.17323/jle.2020.10549

Astuti, R. T. (2018). Improving Students' Reading Comprehension Ability Using Task

Based Language Teaching at MTs Negeri 1 Yogyakarta. Jurnal Pendidikan

Madrasah, 3(2), 279-290.

https://doi.org/https://doi.org/10.21831/lingped.v2i1.28023

Azizi, M., Pavlikova, M., \& Masalimova, A. R. (2020). Exploring Literature Reading Classes in Terms of Types of Feedback Provided by EFL Teachers: Does Teaching

Experience Play A Determining Role? Education and Self Development, 15(3), 1936. https://doi.org/10.26907/esd15.3.02

Bamanger, E. M., \& Gashan, A. K. (2014). In-Service EFL Teachers' Beliefs about

Teaching Reading Strategies. English Language Teaching, 7(8), 14-22.

https://doi.org/10.5539/elt.v7n8p14

Bloemert, J., Jansen, E., \& van de Grift, W. (2016). Exploring EFL Literature

Approaches in Dutch Secondary Education. Language, Culture and Curriculum,

29(2), 169-188. https://doi.org/10.1080/07908318.2015.1136324

Genç, G., Kuluşakli, E., \& Aydin, S. (2016). Exploring Prospective EFL Teachers'

Perceived Self-efficacy and Beliefs on English Language Learning. Australian

Journal of Teacher Education, 41(2), 53-68.

https://doi.org/10.14221/ajte.2016v41n2.4

Handayani, W., \& Setiawan, W. (2018). Physics Student Teachers' Reading Comprehension Skills of Science and Physics Texts. Jurnal Inovasi Pendidikan IPA, 4(2), 203-211. http://journal.uny.ac.id/index.php/jipi

Hosseini, E., Khodaei, F. B., Sarfallah, S., \& Dolatabadi, H. R. (2012). Exploring the Relationship between Critical Thinking, Reading Comprehension and Reading Strategies of English University Students. World Applied Sciences Journal, 17(10), 1356-1364.

https://www.researchgate.net/publication/267722578_Exploring_the_Relationship _Between_Critical_Thinking_Reading_Comprehension_and_Reading_Strategies_ of_English_University_Students

Husain, B., Adam, S. S., \& Ibrahim, I. (2019). Analisis Pola Pengajaran Guru SMP di Kabupaten Pulau Morotai Terhadap Siswa Lamban Belajar. Qalam: Jurnal Ilmu Kependidikan, 8(2), 105-115. https://doi.org/https://doi.org/10.33506/jq.v8i2.687

Khonamri, F. (2015). The Interplay between EFL High School Teachers' Beliefs and Their Instructional Practices. Novitas-ROYAL Research on Youth and Language, 4(1), 96-107.

https://www.researchgate.net/publication/43097071_The_Interplay_between_EFL _High_School_Teachers'_Beliefs_and_Their_Instructional_Practices_Regarding Reading_Strategies

Muslaini. (2017). Strategies for Teaching Reading Comprehension. English Educational Jurnal, 8(1), 66-77. http://jurnal.unsyiah.ac.id/EEJ/article/view/6129 
Nurman, A. (2010). Exploring EFL Teachers' Strategy in Teaching Reading Comprehension: A Case Study at a Junior High School in Riau [Universitas Pendidikan Indonesia]. http://repository.upi.edu/id/eprint/10197

Pourhosein Gilakjani, A., \& Sabouri, N. B. (2016). How Can Students Improve Their Reading Comprehension Skill? Journal of Studies in Education, 6(2), 229. https://doi.org/10.5296/jse.v6i2.9201

Rahimi, M., \& Weisi, H. (2018). The Impact of Research Practice on Professional Teaching Practice: Exploring EFL Teachers' Perception. Cogent Education, 5(1), 1-15. https://doi.org/10.1080/2331186X.2018.1480340

Razali, K., \& Razali, I. (2013). Strategies in Improving Reading Comprehension through Vocabulary Acquisition. Englisia Journal, 1(1), 1-15. https://doi.org/10.22373/ej.v1i1.136

Soemantri, A. S. (2011). Reading Comprehension Problems Encounted by the Students of Higher Education. Jurnal Computech \& Bisnis, 5(2), 74-80. http://jurnal.stmikmi.ac.id/index.php/jcb/article/view/69

Xu, W. (2015). Exploring ESL/EFL Teachers' Pedagogical Content Knowledge on Reading Strategy Instruction. English Language Teaching, 8(11), 155. https://doi.org/10.5539/elt.v8n11p155

Zare, P. (2013). Exploring Reading Strategy Use and Reading Comprehension Success among EFL Learners. World Applied Sciences Journal, 22(11), 1566-1571. https://doi.org/10.5829/idosi.wasj.2013.22.11.1493 